\title{
P53 EXPRESSION IN BENIGN, PREMALIGNANT AND MALIGNANT LESIONS OF ORAL CAVITY
}

\author{
Swayam Prava Pradhan1, Sulata Choudhury2, Anusuya Dash33, D. P. Mishra4, Abhilash N. P5
}

${ }^{1}$ Associate Professor, Department of Pathology, MKCG Medical College, Berhampur, Odisha.

${ }^{2}$ Assistant Professor, Department of Pathology, MKCG Medical College, Berhampur, Odisha.

${ }^{3}$ Assistant Professor, Department of Pathology, MKCG Medical College, Berhampur, Odisha.

${ }^{4}$ Professor, Department of Pathology, MKCG Medical College, Berhampur, Odisha.

${ }^{5}$ Postgraduate Student, Department of Pathology, MKCG Medical College, Berhampur, Odisha.

\section{BACKGROUND}

ABSTRACT

Oral carcinogenesis is a multistep process. The premalignant oral lesions, which develop in the epithelial surface due to chronic exposure to various carcinogens such as tobacco, alcohol, betel chewing and HPV infections get transformed to squamous cell carcinoma in genetically predisposed person. Genetic alterations most commonly associated with oral carcinogenesis is p53 tumour suppressor gene mutation.

The objectives of this study are,

- To find out the incidence of various oral squamous epithelial lesions and to evaluate and compare immunohistochemical expression of $\mathrm{p} 53$.

- To assess the degree of p53 staining intensity from dysplasia to malignancy in differentiating benign and malignant lesions.

\section{MATERIALS AND METHODS}

In this prospective study, histopathological examination and immunohistochemical staining was performed to see the p53 expression in these oral epithelial lesions.

\section{RESULTS}

Immunohistochemical expression of p53 observed in 52 cases of oral epithelial lesions consisting of 8 benign, 11 pre-malignant and 33 squamous cell carcinomas. Out of all, 39 cases were showed p53 positivity. The dysplastic lesions account for 11 cases of which p53 positivity seen in $8(72.72 \%)$ cases; p53 immunoexpression was found positive in 26 (78.78\%) cases of Squamous Cell Carcinoma (SCC). The staining intensity increased from basal to suprabasal region with increase in grade of dysplasias.

\section{CONCLUSION}

Squamous cell carcinoma was found to be the commonest oral malignant epithelial lesion, in which p53 immunoexpression was found in 78.78\% cases. Combined histological analysis with p53 immunoexpression could be a useful and simple molecular marker to detect the possibility of transformation from a premalignant to malignant lesion of oral epithelium.

\section{KEYWORDS}

Oral Squamous Cell Carcinoma, P53, Immunohistochemistry.

HOW TO CITE THIS ARTICLE: Pradhan SP, Choudhury S, Dash A, et al. P53 expression in benign, premalignant and malignant lesions of oral cavity. J. Evolution Med. Dent. Sci. 2016;5(100):7337-7340, DOI: 10.14260/jemds/2016/1661

\section{BACKGROUND}

Head and neck cancers is the $6^{\text {th }}$ leading cancer worldwide, with more than 500000 cases diagnosed every year. The vast majority of head and neck cancers are Oral Squamous Cell Carcinomas (OSCCs) that is arising from the epithelial lining of oral cavity including tongue and lips. ${ }^{1}$

In India, the incidence is 20 per 100,000 population and accounts for over $30 \%$ of all cancers in the country. ${ }^{2}$ Oral squamous cell carcinoma is considered as the result of a multistep process involving a number of aberrant genetic events. Multiple oncogenes, regulatory factors and tumour suppressor genes play a role in development and progression.3,4 Genetically, predisposed persons are

Financial or Other, Competing Interest: None.

Submission 08-11-2016, Peer Review 02-12-2016,

Acceptance 08-12-2016, Published 15-12-2016.

Corresponding Author:

Sulata Choudhury,

Lingaraj Nagar,

Near New Bus Stand,

Berphampur-760001, Odisha.

E-mail: drsulatachudhury@gmail.com

DOI: $10.14260 /$ jemds $/ 2016 / 1661$ influenced by environmental risk factors like tobacco, alcohol, chronic inflammation and viral infection. ${ }^{5}$

Among the gene associated with oral cancer, p53 is a wellknown tumour suppressor gene that is believed to serve as gate keeper against carcinogenesis. Under normal circumstance, the function of $\mathrm{p} 53$ protein is to prevent the propagation of genetically damaged cells. 6,7

Cells with loss of p53 function and abnormal expression of p53 are speculated to undergo malignant transformation. Till date, mutation of p53 gene is one of the most common event in human cancer including oral SCC. ${ }^{8}$

Therefore, the study was performed to assess the immunohistochemical expression of p53 in oral tumorogenesis and to assess the degree of p53 expression form of dysplasia to malignancy.

\section{MATERIALS AND METHODS}

The present study is a prospective study carried out in the Department of Pathology, M.K.C.G. Medical College, Berhampur, Odisha, over a period of 24 months from September 2013 to August 2015 with the approval of Institutional Ethics Committee. Patients with oral lesions 
referred to the Department of Pathology from the Departments of Surgery and E.N.T., were included in our study. The detailed history including duration, site, onset, progression, personal habits like smoking, betel chewing were noted. The clinical diagnosis was recorded. Total number of 52 cases of histologically diagnosed benign, dysplastic and malignant lesions were included in our study.

Mechanical or thermal injury, drug induced oral ulcers, Vit. B12 deficiency oral ulcers and iron deficiency anaemic lesions were excluded from our study. Histopathological examination were done from tissue samples obtained by excisional, incisional or punch biopsy. Histosections were routinely stained with $\mathrm{H}$ and $\mathrm{E}$, p53 immunostaining were also done on the same specimens. Immunohistochemical technique was performed using the DAKO cytochromatin Kit. Section of known p53 positive colon cancer was used as positive control and sections, where the primary antibody had been omitted served as negative control.

Depending upon Staining Intensity, p53 Positivity is Graded According to Cheng et al $2013^{9}$

- $0=$ No staining.

- $1+=$ Weak staining.

- $2+=$ Moderate staining.

- $3+=$ Strong staining.

The Fraction of Stained Cells was Scored According to Following Criteria

- Score 0 ( 0 or $<10 \%$ Positive cancer cells $)$

- Score 1 (11 - 50\% Positive cancer cells)

- $\quad$ Score 2 (51 - 80\% Positive cancer cells)

- $\quad$ Score 3 (> 80\% Positive cancer cells)

The ultimate score attributed to the lesion was always the highest score found in several regions analysed. The consecutive $\mathrm{H}$ and $\mathrm{E}$ stained slides were evaluated by two pathologists without knowing the previous histopathological diagnosis or p53 pattern. Subsequently, p53 stained slides were compared with $\mathrm{H}$ and $\mathrm{E}$ stained slides to establish a relationship between p53 stained areas and respective histopathological diagnosis.

Pearson Chi-square test was applied to calculate $P$ value and considered. $\mathrm{X}^{2}(\mathrm{P}<0.05)$ being statistically significant.

\section{RESULTS}

\section{Observation}

The performed study includes 52 cases of oral lesions. Most of the benign lesions were present in between 20 - 40 years of age, whereas malignant lesions were being diagnosed in between 50 - 60 years of age (Table 1).

\begin{tabular}{|c|c|c|c|c|}
\hline $\begin{array}{c}\text { Age } \\
\text { Group } \\
\text { in } \\
\text { Years }\end{array}$ & Benign & Premalignant & Malignant & Total \\
\hline $20-30$ & 02 & 00 & 02 & 04 \\
\hline $30-40$ & 03 & 04 & 07 & 14 \\
\hline $40-50$ & 01 & 04 & 06 & 11 \\
\hline $50-60$ & 02 & 02 & 12 & 16 \\
\hline $60-70$ & 00 & 01 & 04 & 05 \\
\hline $70-80$ & 00 & 00 & 02 & 02 \\
\hline Total & 8 & 11 & 33 & 52 \\
\hline \multicolumn{2}{|c|}{ Table 1. Oral Lesions According to Age Group } \\
\hline
\end{tabular}

\begin{tabular}{|c|c|c|c|c|}
\hline $\begin{array}{l}\text { Epithelial } \\
\text { Lesions }\end{array}$ & Male & Female & Total & Percentage \\
\hline \multicolumn{5}{|l|}{ Benign Lesions } \\
\hline $\begin{array}{c}\text { Hyperplasia } \\
\text { without } \\
\text { Dysplasia }\end{array}$ & 05 & 02 & 07 & 13.46 \\
\hline $\begin{array}{c}\text { Squamous Cell } \\
\text { Papilloma }\end{array}$ & 01 & 00 & 01 & 1.92 \\
\hline \multicolumn{5}{|l|}{ Dysplasia } \\
\hline Mild & 01 & 01 & 02 & 3.80 \\
\hline Moderate & 01 & 00 & 01 & 1.92 \\
\hline Severe & 04 & 02 & 06 & 11.50 \\
\hline $\begin{array}{l}\text { Carcinoma in } \\
\text { situ }\end{array}$ & 01 & 01 & 02 & 3.80 \\
\hline $\begin{array}{c}\text { Malignant } \\
\text { Lesions } \\
\text { (Squamous Cell } \\
\text { Carcinoma) }\end{array}$ & 28 & 05 & 33 & 63.40 \\
\hline
\end{tabular}

In our series, there were $33(63.4 \%)$ cases of malignant epithelial lesions followed by 11 (21.15\%) cases of premalignant lesions and $8(15.38 \%)$ cases of benign lesions. Malignant lesions are common in males than females (Table 2).

\begin{tabular}{|c|c|c|c|c|}
\hline $\begin{array}{l}\text { Histopathological } \\
\text { Diagnosis }\end{array}$ & Negative & Basal & $\begin{array}{l}\text { Supra } \\
\text { basal }\end{array}$ & Total \\
\hline \multicolumn{5}{|l|}{ Benign Lesions } \\
\hline $\begin{array}{c}\text { Hyperplasia } \\
\text { without } \\
\text { Dysplasia }\end{array}$ & $2(28 \%)$ & $4(57 \%)$ & $1(15 \%)$ & 7 \\
\hline $\begin{array}{l}\text { Squamous Cell } \\
\text { Papilloma }\end{array}$ & $\begin{array}{c}1 \\
(100 \%)\end{array}$ & 0 & 0 & 01 \\
\hline \multicolumn{5}{|l|}{ Dysplasia } \\
\hline Mild & $\begin{array}{c}2 \\
(100 \%)\end{array}$ & 0 & 0 & 02 \\
\hline Moderate & $\begin{array}{c}1 \\
(100 \%)\end{array}$ & 0 & 0 & 01 \\
\hline Severe & 0 & $\begin{array}{c}1 \\
(17 \%)\end{array}$ & $5(83 \%)$ & 06 \\
\hline $\begin{array}{l}\text { Carcinoma in } \\
\text { situ }\end{array}$ & 0 & 0 & $2(100 \%)$ & 02 \\
\hline \multicolumn{5}{|l|}{$\begin{array}{c}\text { Squamous Cell } \\
\text { Carcinoma }\end{array}$} \\
\hline $\begin{array}{c}\text { Well } \\
\text { Differentiated }\end{array}$ & $\begin{array}{c}02 \\
(14 \%)\end{array}$ & $01(2 \%)$ & $\begin{array}{c}11 \\
(78 \%)\end{array}$ & 14 \\
\hline $\begin{array}{c}\text { Moderately } \\
\text { Differentiated }\end{array}$ & $\begin{array}{c}03 \\
(21 \%)\end{array}$ & $\begin{array}{c}02 \\
(14 \%)\end{array}$ & $\begin{array}{c}09 \\
(64 \%)\end{array}$ & 14 \\
\hline $\begin{array}{c}\text { Poorly } \\
\text { Differentiated }\end{array}$ & $\begin{array}{c}01 \\
(50 \%)\end{array}$ & 0 & $\begin{array}{c}01 \\
(50 \%)\end{array}$ & 02 \\
\hline $\begin{array}{l}\text { Verrucous } \\
\text { Carcinoma }\end{array}$ & $\begin{array}{c}01 \\
(33 \%)\end{array}$ & 0 & $\begin{array}{c}02 \\
(77 \%)\end{array}$ & 03 \\
\hline
\end{tabular}

Table 3. P53 Staining Pattern in Oral Epithelial Lesions

In our study, p53 immunoexpression by IHC analysis in oral lesion show suprabasal positivity in $31(59.62 \%)$ cases, basal in $8(15.38)$ cases and negative in $13(25.0 \%)$ cases. 


\begin{tabular}{|c|c|c|c|c|}
\hline \multirow{2}{*}{$\begin{array}{l}\text { Epithelial } \\
\text { Lesions }\end{array}$} & \multicolumn{3}{|c|}{ Intensity } & \multirow{2}{*}{ Total } \\
\hline & Weak & Moderate & Strong & \\
\hline Benign & $\begin{array}{c}2 \\
(40 \%)\end{array}$ & $2(40 \%)$ & $1(20 \%)$ & 5 \\
\hline Premalignant & 0 & $3(38 \%)$ & $\begin{array}{c}5 \\
(62.5 \%)\end{array}$ & 8 \\
\hline Malignant & $\begin{array}{c}2 \\
(8 \%)\end{array}$ & $5(19 \%)$ & $\begin{array}{c}19 \\
(73.07 \%)\end{array}$ & 26 \\
\hline \multicolumn{5}{|c|}{$\begin{array}{c}\text { Table 4. P53 Staining Intensity in Benign, Premalignant } \\
\text { and Malignant Lesions (Ching et al, 2013) }\end{array}$} \\
\hline
\end{tabular}

It was found that $73.07 \%$ malignant and $62.5 \%$ premalignant lesions showed strong p53 positivity including $1 / 5(20 \%)$ of benign lesion.

\section{DISCUSSION}

Mutations in p53 gene are the most common genetic basis of human carcinogenesis. These mutations lead to uncontrolled cell proliferation resulting in further genetic abnormalities and finally malignancy. ${ }^{10} \mathrm{P} 53$ mutation usually shows clonality in cancer, therefore it has occurred in early stages of carcinogenesis in Oral Squamous Cell Carcinoma (OSCC). ${ }^{11}$

In the present study, most common oral epithelial lesion found was OSCC $63.4 \%(n=33)$. Malignant lesions were common in more than 40 years of age group, whereas benign lesions were common in $20-40$ years of age $(n=5)$. The average age was 50 years that was lower than authors reported by Gervasio et al ${ }^{12}$ i.e. 58.6 years and Mirza et al i.e. $54.3 \% .13$ The male and female distribution in our study was 3.7:1. In accordance by Pinholt et al, 14 the male and female ratio is $1.19: 1$. However, in studies of Greek and Brazilian population show quite a higher ratio of $9.2: 1$ to $4.8: 1$ respectively. ${ }^{15,16}$

Epidemiological studies have shown that the site of occurrence of oral S.C.C. differs widely. Tongue, lip and floor of the mouth are the common sites of lesions of S.C.C. In the present study, most common location of oral lesions was tongue, i.e. $48 \%$ of which S.C.C. comprised of $42 \%$ ( 14 cases). This was compatible as compared to most other studies. 16,17,18 The well-differentiated and moderately-differentiated S.C.C. were found in equal number in our study, which contrasts with Haq ME et al who found that poorly differentiated S.C.C. was most prevalent histological variant. Zedan et al reported WDSCC as the most common histological type. ${ }^{16}$

Our attempt to analyse p53 expression showed uniform pattern and intensity of expression in all batches compared at benign, premalignant and malignant lesions suggesting that immunohistochemical procedure utilised was standardised.

In our study $33.3 \%$ of the benign lesions showed p53 negativity $(\mathrm{n}=3), 12.5 \%$ of benign lesions showed suprabasal positivity and $50 \%$ cases of basal positivity. The positive p53 staining in the hyperplastic tissue was likely to be due to in part to the microwave antigen retrieval technique, which has been shown to reduce p53 detection thresholds ${ }^{19}$ due to detection of wild type p53.20 Another possible explanation for the number of positive cases of hyperplasia in present study may be due to proliferation activity in these tissue, as there is a positive relation between p53 expression and cellular proliferation. $21,22,23$

In 11 premalignant cases, p53 positivity was found in $72.72 \%$ cases with an increase in suprabasal positivity as the grade of dysplasia increased. Such pattern of staining was also observed by Cruz et al,24,25 Kerdpon et al,26 Vered et al ${ }^{27}$ and Nasser et al. ${ }^{28}$ These investigators also found that the p53 expression pattern was significantly related to the development of carcinoma. No statistical significance was found between histological grades, possibly due to small number of cases studied.

In our study, $26(78.78 \%)$ cases out of 33 cases of OSCC expressed p53 protein. Our results were similar as reported by Kaur et al. ${ }^{29}$ An interesting observation noted in this study was that well-differentiated tumours had a high p53 immunostaining, while poorly-differentiated SCC showed significant weaker IHC p53 expression in comparison with well-differentiated SCC. These results were consistent with other studies, who have demonstrated statistically significant correlation between histological grade and p53 expression. ${ }^{13,30,31}$

This might be interpreted as most of the mutation in PDSCC is truncating mutations, which may lead to less protein production and absence of its reactivity in nucleus, which in turn indicate an aggressive nature of PDSCC. ${ }^{32,33}$

\section{CONCLUSION}

The most common oral epithelial lesion found in our study is SCC. P53 immunoreactivity is seen in $62.5 \%$ of benign, $72.72 \%$ of premalignant and $78.78 \%$ of squamous cell carcinoma. P53 immunoreactivity has no relation with age, sex and site of lesion. The immunoexpression of p53 increased with increasing grades of dysplasia indicating that they may be used as predictive markers in oral cancer development. Based on these findings, combined histological analysis with p53 immunoexpression, evaluation of premalignant lesions could be improved.

\section{REFERENCES}

1. Ferlay J, Shin HR, Bray F, et al. Estimates of worldwide burden of cancer in 2008: GLOBOCAN 2008. Int J Cancer 2010;127(12):2893-917.

2. Sankaranarayanan R, Ramadas K, Thomas G, et al. Effect of screening on oral cancer mortality in Kerala, India: a cluster-randomised controlled trial. The Lancet 2005;365(9475):1927-33.

3. Scully C, Field JK, Tanzawa H. Genetic aberrations in oral or head and neck squamous cell carcinoma 2: chromosomal aberrations. Oral Oncol 2000;36(4):31127.

4. Vora HH, Shah NG, Patel DD, et al. Prognostic significance of biomarkers in squamous cell carcinoma of the tongue: multivariate analysis. J Surg Oncol 2003;82(1):34-50.

5. Choi S, Myers JN. Molecular pathogenesis of oral squamous cell carcinoma: implications for therapy. J Dent Res 2008;87(1):14-32.

6. Prives C, Hall PA. The p53 pathway. J Pathol 1999;187(1):112-26.

7. Abbas NF, Labib El-Sharkawy S, Abbas EA, et al. Immunohistochemical study of p53 and angiogenesis in benign and preneoplastic oral lesions and oral squamous cell carcinoma. Oral Surg Oral Med Oral Pathol Oral Radiol Endod 2007;103(3):385-90.

8. Whyte DA, Broton CE, Shillitoe EJ. The unexplained survival of cells in oral cancer: what is the role of p53? J Oral Pathol Med 2002;31(3):125-33. 
9. Cheng AN, Jiang SS, Fan CC, et al. Inceased Cdc7 expression in a marker of oral squamous cell carcinoma and overexpression of $\mathrm{Cdc} 7$ contributes to the resistance to DNA-damaging agents. Cancer Lett 2013;337(2):21825.

10. Meszaros N, Belengeanu D, Stoicanescu D, et al. Analysis of numerical aberration of chromosome 17 and TP53 gene deletion/amplification in human oral squamous cell carcinoma using dual colour fluorescence insitu hybridization. Tom 2010;17(1):142-6.

11. Kashiwazaki $H$, Tonoki $H$, Tada $M$, et al. High frequency of p53 mutations in human oral y epithelial dysplasia \& primary SCC detected by yeast functional assay. Oncogene 1997;15(22):2607-74.

12. Gervasio OL, Dutra RA, Tartaglia SM, et al. Oral squamous cell carcinoma: a retrospective study of 740 cases in a Brazilian population. Braz Dent J 2001;12(1):57-61.

13. Mirza T, Alam SM, Pringle IL, et al. Molecular analysis of human papillomavirus and oncosuppressor genes in tobacco related oral cancer. Pak J Otolaryngol 1998;14:27-33.

14. Pinholt EM, Rindum J, Pindborg JJ. Oral cancer: a retrospective study of 100 Danish cases. Br J Oral Maxillofac Surg 1997;35(2):77-80.

15. Antoniades DZ, Stynidis K, Papanatou P, et al. Squamous cell carcinoma of the lips in a northern greek population. Evaluation of prognostic factors on 5-year survival rate-I. Eur J Cancer B Oral Oncol 1995;31B(5):333-9.

16. Zedan W, Mourad MI, Abd El-Aziz SM, et al. Cytogenetic significance of chromosome 17 aberrations and P53 gene mutations as prognostic markers in oral squamous cell carcinoma. Diagn Pathol 2015;10:2.

17. Haq MEV, Abid I, Hanit MK, et al. Frequency and pattern of oral and Maxillo-facial carcinoma. J Orofacial Res Ann 2009;15(4):171-5.

18. Rich AM, Kerdpon D, Reade PC. p53 expression in oral precancer \& cancer. Aust Dent J 1999;44(2):103-5.

19. Dowell SP, Ogden GR. The use of antigen retrieval for immunohistochemical detection of p53 over-expression in malignant and benign oral mucosa: a cautionary note. J Oral Pathol Med 1996;25(2):60-4.

20. McKee PH, Hobbs C, Hall PA. Antigen retrieval by microwave irradiation lowers immunohistological detection thresholds. Histopathology 1993;23(4):377-9.
21. Lippman SM, Shin DM, Lee JJ, et al. p53 and retinoid chemo-prevention of oral carcinogenesis. Cancer Res 1995;55(1):16-9.

22. Warnakulasuriya KAAS, Johnson NW. Association of overexpression of p53 oncoprotein with the state of cell proliferation in oral carcinoma. J Oral Pathol Med 1994;23(6):246-50.

23. Nylander K, Stening R, Gustafsson $\mathrm{H}$, et al. p53 expression and cell proliferation in squamous cell carcinomas of the head and neck. Cancer 1995;75(1):87-93.

24. Cruz I, Napier SS, van der Waal I, et al. Suprabasal p53 immunoexpression is strongly associated with high grade dysplasia and risk for malignant transformation in potentially malignant oral lesions from Northern Ireland. J Clin Pathol 2002;55(2):98-104.

25. Cruz IB, Snijders PF, Meijer CJ, et al. p53 expression above the basal cell layer in oral mucosa is an early event of malignant transformation and has predictive value for developing oral squamous cell carcinoma. J Pathol 1998;184(4):360-8.

26. Kerdpon D, Rich AM, Reade PC. Expression of p53 in oral mucosal hyperplasia, dysplasia and squamous cell carcinoma. Oral Dis 1997;3(2):86-92.

27. Vered M, Allon I, Dayan D. Maspin, p53, p63, and Ki- 67 in epithelial lesions of the tongue: from hyperplasia through dysplasia to carcinoma. J Oral Pathol Med 2009;38(3):314-20.

28. Nasser W, Flechtenmacher C, Holzinger D, et al. Aberrant expression of p53, p16INK4a and Ki-67 as basic biomarker for malignant progression of oral leukoplakias. J Oral Pathol Med 2011;40(8):629-35.

29. Kaur J, Srivastava A, Ralhan R. Prognostic significance of p53 protein over expression in betel \& tobacco related oral oncogenesis. Int J Cancer 1990;79(4):370-5.

30. Yan JJ, Tzeng CC, Jin YT. Overexpression of p53 protein in squamous cell carcinoma of buccal mucosa and tongue in Taiwan: an immunohistochemical and clinicopathological study. J Oral Pathol Med 1996;25(2):55-9.

31. Mullel PAJ, Vousden KH. p53 mutation in cancer. Nat Cell Biol 2013;15(1):2-8.

32. Vogelstein B, Lane D, Levine AJ. Surfing the p53 network. Nature 2000;408(6810):307-10.

33. Vousden KH, Lu X. Live or let die:The cells response to p53. Nat Rev Cancer 2002;2(8):594-604. 